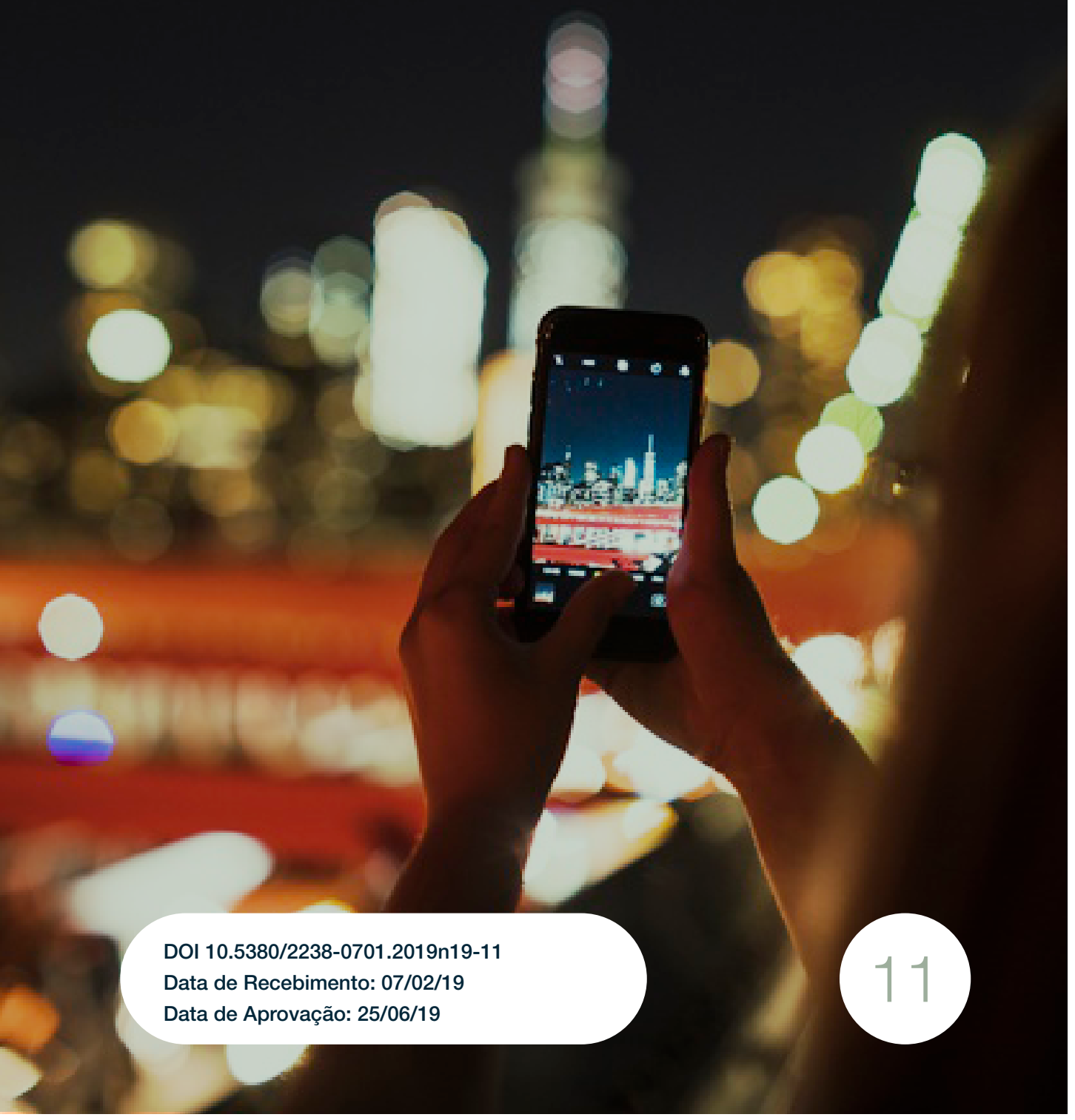


Imagens técnicas e o pensamento imagético em Vilém Flusser: diálogos para uma epistemologia da imaginação 


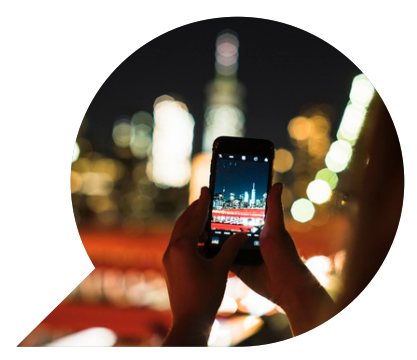

\title{
Imagens técnicas e o pensamento imagético em Vilém Flusser: diálogos para uma epistemologia da imaginação
}

\author{
Technical images and visual thinking in Vilém Flusser: \\ dialogues for an epistemology of the imagination \\ Imágenes técnicas y el pensamiento imagético en \\ Vilém Flusser: diálogos para una epistemología de la \\ imaginación
}

DANIEL MELO RIBEIRO ${ }^{1}$

Resumo: Este artigo propõe uma reflexão sobre as imagens técnicas em Vilém Flusser. Considerando a atual proliferação de superfícies e aparatos de reprodução de imagens, Flusser levanta a necessidade de desenvolvermos uma faculdade cognitiva capaz de decifrar como operam as imagens técnicas. Essa faculdade, denominada tecnoimaginação, estimularia o pensamento crítico sobre as imagens. Para elaborar esse argumento, recuperamos dois temas centrais em sua obra: a escalada da abstração e as caixas pretas. A partir desse fundamento, sugerimos que o incentivo ao pensamento imagético passa não somente pelo debate sobre a arte contemporânea, mas pelo diálogo com outros pensadores que também refletiram sobre a epistemologia da imaginação.

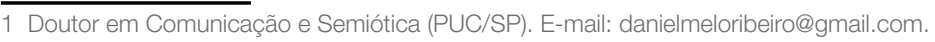


Palavras-chave: Imagem técnica; Vilém Flusser; Aparelho.

Resumen: This article discusses the topic of technical images in Vilém Flusser. Considering the current context characterized by the proliferation of surfaces and technical devices of image reproduction, Flusser proposes a new cognitive skill. This faculty, called technoimagination, would help understanding how technical images operate, stimulating a critical thinking about images. In order to elaborate this argument, this article brings a brief retrospective on two main topics in Flusser's work: the steps of abstraction and the black boxes (or imaging devices). On that account, we suggest that the improvement of critical visual thinking embraces not only the debate on contemporary art, but also the dialogue with other philosophers who, along with Flusser, reflected on the epistemology of the imagination.

Palabras clave: Technical images; Vilém Flusser; Devices

Abstract: Este artículo propone una reflexión sobre las imágenes técnicas en Vilém Flusser. Considerando la actual proliferación de superficies y aparatos técnicos de reproducción de imágenes, Flusser plantea la necesidad de desarrollar una facultad cognitiva capaz de descifrar cómo operan las imágenes técnicas a nuestro alrededor. Esta facultad, denominada tecnoimaginación, estimularía el pensamiento crítico sobre las imágenes. Para elaborar este argumento, proponemos una breve retrospectiva sobre dos temas centrales en la obra de Flusser: la escalada de la abstracción y las cajas negras. A partir de ese fundamento, sugerimos que el incentivo al pensamiento imagético pasa no sólo por el debate sobre el arte contemporáneo, sino por el diálogo con otros pensadores que también reflexionaron sobre la epistemología de la imaginación.

Keywords: Imagen técnica; Vilém Flusser; Aparato 


\section{Introdução}

Sabemos que o estudo das imagens, em seus aspectos cognitivos, semióticos, midiáticos, artísticos e culturais, revela-se como um verdadeiro "empreendimento interdisciplinar" (SANTAELLA; NÖTH, 1997, p. 13), mobilizando repertórios que transitam desde a filosofia até a comunicação. Neste estudo, em particular, focalizamos um tipo de imagem: a imagem técnica, processada por aparelhos mecânicos ou digitais. Assim, nossa intenção é refletir sobre o atual cenário midiático contemporâneo, caracterizado pela proliferação de aparatos técnicos de reprodução de imagens, tais como câmeras, celulares e computadores portáteis. Partimos da necessidade de se compreender o estatuto epistemológico das imagens técnicas, colocando a seguinte pergunta: que modelos conceituais poderiam nos orientar nesse ambiente saturado de imagens?

Nossa reflexão sobre as imagens técnicas é amparada pelo pensamento de Vilém Flusser. Flusser foi um filósofo de origem tcheca que estabeleceu estreitos vínculos com o Brasil, tendo vivido em nosso país por mais de 30 anos. Seus textos sobre a linguagem, os dispositivos comunicacionais, os códigos e as mensagens ganharam um recente destaque nos estudos da mídia, sobretudo na Alemanha (FELINTO; SANTAELLA, 2012). Dentre as inúmeras referências conceituais trabalhadas pelo autor, destacam-se a cibernética e a fenomenologia. Seu olhar sobre os fenômenos da comunicação rompe fronteiras disciplinares e levanta reflexões profundas, incluindo temas como a "codificação da experiência" (CARDOSO, 2007, p. 12) e a materialidade dos suportes midiáticos. De acordo com Arlindo Machado (2005, p. 73), a originalidade das reflexões de Flusser o credencia a ocupar uma posição de destaque "com relação tanto à posição tecnófila quanto à corrente tecnófoba, ambas atualmente em vigor". Nesse sentido, Flusser teria muito a contribuir com o debate crítico a respeito das novas tecnologias no Brasil, na medida em que seu pensamento não se filia a discursos utópicos importados de outras realidades socioeconômicas, sejam eles "neopositivistas" ou "apocalípticos" (MACHADO, 2005, p. 73).

A imagem e a imaginação ocupam um lugar proeminente em suas publicações. Neste artigo, pretendemos explorar como Flusser entende as imagens em seu potencial cognitivo e semiótico. Ou seja, discuti- 
remos a maneira como as imagens atuam tanto na representação do mundo objetivo quanto na geração de conhecimentos, alimentando o pensamento conceitual. A partir desse fundamento, sugerimos que o incentivo ao pensamento imagético passa não somente pelo debate sobre a arte contemporânea, mas pelo diálogo com outros pensadores que também refletiram sobre a epistemologia da imaginação, tais como Walter Benjamin e Charles Peirce. No entanto, para compreendermos como as imagens podem desempenhar tais funções, é necessária uma breve explicação sobre como Flusser elabora os diferentes graus de abstração do pensamento, em seus respectivos suportes materiais.

\section{A escalada da abstração}

Em uma definição bastante sucinta (mas não menos profunda), Flusser define a cultura como um "dispositivo para legar informações adquiridas" (FLUSSER, 2014, p. 34). Dessa maneira, o ser humano se vê empenhado em registrar informações nos diferentes objetos do seu cotidiano, a fim de que ele próprio, bem como as próximas gerações, possam se beneficiar de seu uso. Esse processo de gravar informações em objetos materiais iniciase com um primeiro gesto de abstração, ocorrido há milhares de anos com os primeiros hominídeos. Trata-se do gesto de "arrancar algo do mundo da vida e transformá-lo em objeto" (FLUSSER, 2014, p. 37). A "objetificação" de algo tridimensional que esteja ao alcance das mãos (uma pedra, por exemplo) inaugura a elaboração de um problema e estabelece uma primeira abstração da relação entre sujeito e objeto. Pensar sobre esse problema leva o homem a manipular esses objetos e gerar instrumentos que se tornam, progressivamente, mais sofisticados.

O próximo gesto de abstração consiste na criação de imagens em superfícies. Diante dos fenômenos do seu cotidiano, o homem se afasta um pouco mais dos objetos, em um lugar onde suas mãos não mais os alcançam. Esse recuo the permite conceber cenas e recuperar, em sua mente, pontos de vista. No entanto, essa apreensão visual dos fenômenos é fugaz e subjetiva. Ela requer a sua fixação em um suporte (por exemplo, na parede de uma caverna). Esse gesto é definido por Flusser como imaginação, e consiste em "rastejar para dentro de si mesmo, de lá olhar para fora, fixar o que foi avistado, usar uma parede de pedra como apoio 
de memória e, assim, fixar o avistado, para que outros possam decifrálo" (FLUSSER, 2014, p. 125). Dessa maneira, a imagem atua como um "armazenador material de informações" (FLUSSER, 2014, p. 127), composta de símbolos e instruções intersubjetivadas. A fixação da imagem em um suporte socialmente compartilhável permite que outros possam melhor compreender os objetos que ela representa, tornando-se um guia para a ação e para a interpretação do mundo.

Nesse contexto, as imagens adquirem uma relevante função na escalada de abstração do pensamento conceitual. Trata-se de imagens que se referem a objetos ausentes, cujo significado pode ser socialmente partilhado, orientando ações no mundo da vida. "A imagem visa representar objetos - ou, para dizer mais elegantemente, o vetor de significação da imagem aponta para objetos" (FLUSSER, 2014, p. 128). O gesto de imaginação, portanto, cria e estabelece a função semiótica das imagens.

No entanto, para além dessa função prática inicial, as imagens passam também a representar cenas que, gradativamente, tendem a se distanciar dos fatos concretos. O ímpeto para a representação de cenas míticas e fantásticas, fruto da imaginação efervescente do homem, leva-o a adorar imagens que "dissimulam o mundo completamente" (FLUSSER, 2014, p. 130). As imagens não mais apontam para objetos concretos do mundo, dando lugar à idolatria (adoração de imagens) e ao paganismo. Então, faz-se necessário um novo passo de abstração, capaz de superar essas representações ditas falsas e imperfeitas.

A invenção da escrita linear vem, justamente, tentar romper com as imagens míticas e mágicas. A invenção de um sistema altamente codificado, baseado na sucessão de símbolos fonéticos encadeados de maneira linear, tende a se impor sobre o pensamento por superfícies, expulsando as imagens "da vida cotidiana para o gueto das "belas artes'" (FLUSSER, 2011a, p. 116). "As letras formam linhas, as linhas formam textos, e esses textos avançam contra as imagens" (FLUSSER, 2014, p. 135). Flusser afirma que essa maneira de estruturação do pensamento irá, por consequência, inaugurar a consciência histórica. "Sua intenção é criar uma consciência livre de todos os mitos e toda a magia, que pensa e age, que age historicamente - a consciência histórica, política" (FLUSSER, 2014, p. 135). Assim, a progressiva alfabetização da população e a disseminação das técnicas de impressão conduziram a uma mudança significativa em direção ao pensamento conceitual e ao florescimento das ciências. 
Contudo, a própria escrita também está sujeita a ambiguidades. Cada língua possui suas particularidades semânticas. As palavras, frases e textos também abrigam polissemias. "Cada língua é magnífica, como estrutura, como ritmo, como melodia, como infinidade de conotações" (FLUSSER, 2014, p. 146). Além disso, os textos, que inicialmente pretendiam descrever as imagens e desmistificá-las, também estiveram sujeitos ao esvaziamento da sua função descritiva, perdendo o contato com o mundo e a experiência concreta. Nesse sentido, a "textolatria" também pode ser tão maliciosa quanto a "idolatria". Portanto, uma vez mais se faz necessário alcançar um novo salto de abstração, agora em direção ao cálculo.

Paralelamente à invenção do alfabeto, emerge o código numérico. O código numérico permite a abstração de um gesto também bastante antigo, que é o gesto de contar. A diferença em relação ao alfabeto é que o código numérico estrutura o pensamento de maneira clara e distinta. Ao perceber que a tarefa de se descrever o mundo era suficientemente árdua, cogitou-se conceber o comportamento da natureza a partir de regras matemáticas. Nesse sentido, "o código numérico é incomparavelmente mais adequado do que o código de letras para reconhecer o mundo. O mundo é indescritível, mas é perfeitamente contável" (FLUSSER, 2014, p. 157). Aplica-se um raciocínio aritmético à extensão espacial do mundo, uma espécie de grid, capaz de localizar qualquer ponto por meio de coordenadas e equações. "Agora, tudo pode ser formulado em números, (...) tudo pode ser expresso em equações diferenciais. Somos deus. Somos oniscientes" (FLUSSER, 2014, p. 163).

A crescente sofisticação desse pensamento aritmético provoca uma intensa propagação da técnica, culminado na proliferação de máquinas. As máquinas, inicialmente projetadas para automatizar gestos humanos (mover, carregar, apertar, cortar), passam também a potencializar a própria ação de calcular. Com uma simplificação extrema do código numérico - transformando-o em uma alternância binária de estados - são criadas máquinas calculadoras cada vez mais poderosas, os computadores.

Nesse ponto, Flusser vislumbrou, na emergência da linguagem digital, um desdobramento do último passo na escalada da abstração. No entanto, o filósofo faleceu pouco tempo antes do avanço computacional e da expansão das redes de comunicação digitais. Ainda assim, suas reflexões sobre os códigos computacionais, aplicadas não somente ao cálculo, mas sobretudo à recriação de textos e imagens digitais, anteciparam questões 
pertinentes ao debate contemporâneo. Suas opiniões, muito longe de estacionarem num otimismo ingênuo, proporcionam análises críticas sobre a maneira como as mensagens são codificadas e transmitidas. Uma dessas questões diz respeito ao pensamento imagético, responsável por decifrar as atuais imagens técnicas.

\section{A imagem técnica e os aparelhos}

É importante lembrar que esses saltos de abstração não indicam uma supressão definitiva de linguagens em detrimento de outras. De acordo com Santaella (2007, p. 122), "a emergência de um novo sistema não desloca o que veio antes, mas adere como uma nova camada, tornando a ecologia midiática ainda mais estratificada". O próprio Flusser (2008) reconhece que a escalada da abstração não representa, necessariamente, uma progressão de saltos que foram tomados numa sequência linear. Seu propósito foi elaborar um modelo didático de raciocínio em que ele pudesse se apoiar para melhor evidenciar o problema atual das imagens técnicas, distinguindoas das imagens tradicionais. Além disso, imagens, textos, cálculos e bits convivem numa certa dialética interna, uma espécie de constante tensão. Dessa maneira, os passos rumo à abstração não constituem uma sucessão estável e ininterrupta, sendo "sempre interrompidos por passos de volta ao concreto" (FLUSSER, 2008, p. 18).

Flusser propõe uma alternância no predomínio de uma mídia sobre a outra, especialmente entre textos e imagens. Se, num determinado momento, o pensamento textual se sobrepõe às imagens, atualmente "são as superfícies, e não mais as linhas textuais, que codificam preferencialmente nosso mundo" (FLUSSER, 2011a, p. 113). Flusser ressalta que nossa atual sociedade está cercada de superfícies (planos bidimensionais) que irradiam imagens codificadas. Num certo sentido, portanto, há um movimento de retorno, que se iniciou com as imagens na chamada "pré-história" e alcançou a escrita alfabética, estabelecendo o pensamento histórico, para então retornar às imagens. Contudo, há uma diferença fundamental entre as atuais imagens e as imagens "pré-históricas" (ou seja, imagens que antecederam a invenção da história pela escrita linear). Trata-se, agora, de imagens técnicas, imagens criadas por aparelhos, cujo marco é estabelecido pela invenção do aparelho fotográfico. "É com a fotografia que se inicia, portanto, 
um novo paradigma na cultura do homem, baseado na automatização da produção, distribuição e consumo da informação" (MACHADO, 2005, p. 74).

Segundo Baitello Jr. (2008), a imagem técnica (ou tecno-imagem) origina-se no contexto da pós-escrita, caracterizado, no último estágio da escalada da abstração, pela eclosão do pensamento aritmético sobre o pensamento linear do alfabeto textual. Cabe ressaltar que, na base da aritmética, encontram-se operações de cálculo, cuja origem remete à contagem de pequenas pedras lisas e arredondadas (calculus). Uma vez que as imagens técnicas são criadas e codificadas por cálculos (pontos ou pixels), elas não mais podem ser qualificadas por seu aspecto bidimensional. Por trás da aparente superficialidade, encontra-se uma trama de pontos que acabam por ocultar os intervalos entre eles, enganando a visão.

O fato de uma imagem técnica ser construída a partir de pontos indica que seu processo de criação não se origina de um gesto humano. Diferentemente de uma pintura ou de um desenho na parede, a imagem técnica é processada por uma máquina. Essa é uma condição que não deve ser desprezada. A imagem técnica não é uma imagem ingênua. Ela surge de uma operação mecânica, um output gerado por uma caixa preta (FLUSSER, 2011b), cujo funcionamento interno é muitas vezes ignorado por seu operador. A imagem fotográfica, em particular, é travestida de uma pretensa objetividade, ao captar e registrar uma cena por meio de sua lente objetiva. Porém, a câmera fotográfica é fruto de um pensamento mecanicista, que visa projetar aparelhos programados para operar de acordo com um determinado algoritmo. O fotógrafo se torna um funcionário de uma máquina fechada, sem muita liberdade para interferir nas regras prédefinidas do aparelho (semelhante a um operário que pressiona botões em uma máquina industrial, alienado do processo como um todo). "Na realidade, os aparelhos transcodam sintomas em símbolos, e o fazem em função de determinados programas" (FLUSSER, 2011a, p. 118, grifo do autor). Tais regras se aplicam a todos os outros aparelhos geradores de imagens, sejam eles câmeras cinematográficas, televisores, computadores, projetores e telas. Idem para as imagens digitais, criadas por transcodificação de bits.

As imagens técnicas, portanto, indicam um problema: elas encapsulam uma lógica algorítmica e opaca de codificação, que ilude o observador quanto à sua aparente superficialidade. Ademais, as imagens técnicas são frutos de aparelhos programados para gerar um certo número finito de 
possibilidades previstas por seu algoritmo. Cabe ao funcionário operar a máquina dentro das categorias contidas no sistema, limitando-se a escolher modelos previamente definidos, ou meras atualizações de algumas dessas potencialidades inscritas no aparelho (MACHADO, 2005, p. 75). Diante disso, torna-se fundamental decifrar como operam as imagens técnicas ao nosso redor, caso contrário, permaneceremos como meros funcionários de um aparelho regido por algoritmos, cujo acesso é interditado às nossas interferências.

Como, então, superar essa limitação inerente às imagens técnicas? Para atacar o problema colocado pelas tecno-imagens, Flusser convocanos a um exercício de crítica. Segundo Flusser, crítica é a ação de romper um fenômeno para se revelar o que está oculto por trás dele (FLUSSER, 2014). A crítica das imagens técnicas consiste em "des-ocultar os programas por detrás das imagens" (FLUSSER, 2008, p. 29). Ou seja, abrir a caixa preta e expor as entranhas que compõem o mecanismo responsável por gerar imagens. Nesse sentido, a crítica agrega um caráter revolucionário, contestador, provocativo. Ir contra o programa significa não mais operar o aparelho de acordo com o projeto, apertando botões conforme o manual, e sim subvertê-lo em sua própria lógica. Em outras palavras, exercer a liberdade de "jogar contra o aparelho", ou "conscientemente obrigar o aparelho a produzir imagem informativa que não está em seu programa" (FLUSSER, 2011b, p.106-107).

Em que contexto essa liberdade de atuar contra o aparelho pode ser exercida? De acordo com Arlindo Machado (2005), o questionamento crítico que se coloca sobre as imagens técnicas deve se afastar dos horizontes determinados pelas soluções do mercado e da indústria, a fim de explorar questões como o desvio, o estranhamento, as incertezas e o desconforto. Essas categorias se encontram, justamente, no campo da arte contemporânea. "A perspectiva artística é certamente a mais desviante de todas, uma vez que ela se afasta em tal intensidade do projeto tecnológico originalmente imprimido às máquinas e programas que equivale a uma completa reinvenção dos meios" (MACHADO, 2005, p. 76-77). É nessa reinvenção dos meios e das linguagens promovida pelas artes que Arlindo Machado explorou o pensamento crítico sobre as imagens técnicas vislumbrado por Flusser. 


\section{A crítica das imagens técnicas através da arte contemporânea}

O caráter contestador e crítico da arte desponta no contexto onde as imagens técnicas assumem um protagonismo irrevogável, mais precisamente, nas primeiras décadas do século $X X$. $O$ amadurecimento das técnicas fotográficas e a consequente invenção do cinema abalaram decisivamente o campo das artes plásticas, conduzindo os artistas a explorar expressões estéticas alternativas, diante dessa nova proposta de registro e captura de imagens. Como afirma Walter Benjamin, em seu ensaio "A obra de arte na era de sua reprodutibilidade técnica" (BENJAMIN, 2012), a reprodução mecânica de imagens levou ao que ele caracterizou como "perda da aura" dos objetos artísticos tradicionais. A aura - entendida como a capacidade de certos objetos artísticos de "retribuir o olhar" (BENJAMIN, 2015, p. 143) - esvazia-se diante da reprodução em massa das imagens. No entanto, além dessa perda, a introdução da fotografia provocou uma profunda mudança no papel das artes. "Em vez de fundar-se no ritual, ela passa a fundar-se em outra práxis: a política” (BENJAMIN, 2012, p. 186). Em outras palavras, a invenção da fotografia não somente alterou o caráter ritualístico da arte, na medida em que questionou sua autenticidade e sua função mimética, como também permitiu a emergência da arte politizada.

Mas é no campo da arte eletrônica que Arlindo Machado (1999) concentra seus argumentos sobre projetos estéticos que questionam os aparelhos e os programas. Machado critica a ideia de Flusser de que as potencialidades de uma máquina geradora de imagens técnicas - como uma câmera fotográfica ou um computador - sejam finitas. Por se tratarem de máquinas semióticas, os limites contidos em seus programas, na prática, ainda não foram completamente esgotados.

Dada a complexidade dos conceitos invocados na concepção de uma máquina semiótica, poderíamos então dizer que sempre existirão potencialidades dormentes e ignoradas, que o artista inquieto acabará por descobrir, ou até mesmo por inventar, ampliando portanto o universo das possibilidades conhecidas de determinado meio (MACHADO, 1999, p. 35).

Como exemplos, Machado cita obras de artistas como Nam June Paik, 
que, com o auxílio de ímãs, "desvia o fluxo dos elétrons no interior do tubo iconoscópico da televisão, para corroer a lógica figurativa de suas imagens" (MACHADO, 1999, p. 36); ou dos fotógrafos Frederic Fontenoy e Andrew Davidhazy, que modificaram "o mecanismo do obturador da câmera fotográfica” (MACHADO, 1999, p. 36) para alterar o tempo de congelamento das imagens; ou ainda do artista brasileiro Waldemar Cordeiro, pioneiro no uso das imagens digitais, responsável por promover uma conotação política e uma "dimensão crítica à computer art, acrescentando às imagens o comentário social que não havia na produção mundial” (MACHADO, 2005, p. 77). De acordo com Machado, esses exemplos desafiam o determinismo tecnológico embutido nas máquinas e aparelhos, superando o deslumbramento pelo primor técnico das ferramentas. Em uma sociedade "tecnocrática", o papel da arte se torna ainda mais relevante, na medida em que ela se recusa a submeter-se à lógica pré-definida dos aparelhos e das máquinas semióticas, reinventando as funções e finalidades da tecnologia (MACHADO, 1999).

\section{Por uma leitura crítica das imagens midiáticas contemporâneas}

A arte contemporânea abre uma vertente reconhecidamente rica para endereçar parte dos problemas colocados pelas imagens técnicas. Por outro lado, pretendemos apontar um outro caminho através do qual esse debate ainda pode ser, futuramente, explorado de maneira frutífera: os aspectos cognitivos que envolvem a interpretação de imagens. Em que medida a emergência das imagens técnicas demanda mudanças em nosso aparato cognitivo de compreensão das imagens? Diante do retorno da visualidade anunciado por Flusser, deveríamos desenvolver uma nova capacidade de ler imagens? O próprio Flusser sinaliza algumas pistas nessa direção, propondo uma capacidade que ele denominou de tecnoimaginação.

A leitura de imagens técnicas em superfícies aparentes requer uma estrutura de pensamento diferente da estrutura que estávamos acostumados. "Tal imaginação produtora de imagens tradicionais é diametralmente oposta à imaginação produtora de tecno-imagens" (FLUSSER, 2008, p. 22). Contra essa ameaça e em direção a uma emancipação do pensamento programado pelas imagens técnicas, Flusser propõe o desenvolvimento 
de uma nova faculdade, chamada de tecnoimaginação: "a capacidade de decifrar tecno-imagens. Capacidade esta que tem a ver com o pensamento formal, tal como este vai se estabelecendo na informática, cibernética e na teoria dos jogos" (FLUSSER, 2011a, p. 120).

Mas o que seria exatamente esse "pensamento formal", apontado por Flusser como um possível caminho para a leitura crítica das imagens técnicas? No trecho acima, o autor situa esse pensamento no domínio da informática e da cibernética. Seria a atual tendência que proclama que todo jovem deve aprender a programar computadores? Ou que toda criança deveria se "alfabetizar digitalmente" nas escolas? Ambas parecem apontar muito mais para um discurso de adequação à nova realidade do mercado de trabalho - que no fundo anseia por profissionais mais qualificados para ocupar seus postos - do que necessariamente uma mobilização crítica a respeito da tecnologia.

Em outro contexto, Flusser desenvolve essa ideia da seguinte maneira. Num ensaio chamado "Linha e superfície" (FLUSSER, 2007), o filósofo retoma a constatação de que as imagens em superfície ganharam uma notável relevância no cenário contemporâneo. No entanto, Flusser elabora um argumento favorável ao pensamento imagético, contrastando-o com o pensamento linear típico do código escrito. Segundo ele, o retorno das imagens em superfície requer uma compreensão sobre como opera o pensamento conceitual por imagens. Pensar sobre imagens pressupõe um processo de leitura distinto da leitura textual. Em suas palavras, "as linhas escritas relacionam seus símbolos a seus significados, ponto por ponto (elas ‘concebem' os fatos que significam), enquanto as superfícies os relacionam por meio de um contexto bidimensional (elas 'imaginam' os fatos que significam)” (FLUSSER, 2007, p. 113). De um lado, a representação por linhas é capaz de estabelecer uma mediação de natureza mais clara e objetiva, porém mais restrita. Do outro lado, a representação por superfícies cria uma mediação mais ambivalente e subjetiva, porém mais rica.

O fato é que o segundo tipo de pensamento - por superfícies - não vinha sendo colocado em seu devido patamar de relevância desde a emergência da escrita e do pensamento estruturado em linhas. "A epistemologia ocidental é baseada na premissa cartesiana de que pensar significa seguir a linha escrita, e isso não dá crédito à fotografia como uma maneira de pensar" (FLUSSER, 2007, p. 111). Essa tendência, no entanto, parece se reverter, dado o recente vigor com que as imagens têm ressurgido. 
As ciências e outras articulações do pensamento linear, tais como a poesia, a literatura e a música, estão cada vez mais se apropriando de recursos do imagético pensamento-em-superfície, e assim o fazem por causa do avanço tecnológico da mídia de superfície (surface media). E essa mídia, incluindo pinturas e anúncios publicitários, está recorrendo cada vez mais aos recursos do pensamento linear (FLUSSER, 2007, p. 118).

No trecho acima, Flusser parece apostar numa espécie de interpolação de matrizes (visual e verbal), prevendo o que, em anos seguintes, ocorreria com a linguagem multimidiática. Mas, para além dessa possibilidade, Flusser também acredita que o pensamento imagético possa alcançar um outro nível de abstração, sendo capaz de articular conceitos: "o pensamento imagético está se tornando capaz de pensar conceitos. Ele é capaz de transformar o conceito em seu 'objeto' e pode, portanto, tornar-se um metapensamento de um modo de pensar conceitual" (FLUSSER, 2007, p. 118, grifo nosso).

Tal reflexão indica que a tecnoimaginação sugerida por Flusser passa pelo entendimento mais profundo de dois aspectos do pensamento visual, em particular: (1) o pensamento capaz de operar ações de tradução entre matrizes da linguagem; e (2) o pensamento visual, capaz de atuar em nível conceitual, ou um metapensamento. Assim, sugerimos que uma maneira de se explorar esse tema seria estabelecendo pontes entre a obra de Vilém Flusser com outros autores que também trabalharam essas questões, a saber: Walter Benjamin e Charles Peirce.

\section{Flusser e Benjamin: tradução e imagens técnicas}

Afinidades entre Flusser e Benjamin foram exploradas pelos pesquisadores Sjoukje van der Meulen (2010) e por Márcio Seligmann-Silva (2009; 2014). Esse último autor argumenta que uma das aproximações entre os filósofos se encontra nas pontes e nos "saltos entre universos" promovidos pela tradução. Como se sabe, Flusser foi, além de poliglota, um obcecado pelo tema. Sua atração pela tradução se reflete não somente no exercício constante de escritura dos mesmos textos em várias línguas 
como também nas possibilidades de tradução "entre o discurso verbal e o imagético, entre o conceito e o algoritmo, entre a música e as demais linguagens" (SELIGMANN-SILVA, 2009, p. 5). O interesse pela linguagem universal também foi trabalhado por Benjamin em seus ensaios de juventude (BENJAMIN, 2013), assunto que posteriormente inspirou os poetas concretos a respeito das potencialidades das traduções intersemióticas (CAMPOS, 1997; PLAZA, 2013).

No entanto, podemos afirmar que a aproximação mais contundente entre Flusser e Benjamin encontra-se na reflexão sobre as imagens técnicas e seus mecanismos de reprodução mecânica. Segundo Seligmann-Silva, a teoria das imagens técnicas de Vilém Flusser "pode ser colocada ao lado da reflexão benjaminiana sobre a obra de arte na época da sua reprodução técnica" (SELIGMANN-SILVA, 2014, p. 226). De acordo com Meulen (2010), a Filosofia da Caixa-Preta de Flusser (2011b) é "baseada na premissa de que há uma diferença fundamental entre as imagens técnicas e as imagens tradicionais, que é exatamente a mesma afirmação na base do texto de Benjamin sobre A obra de arte..." (MEULEN, 2010, p. 188).

Benjamin foi um dos primeiros pensadores a perceber, com clareza, os impactos das imagens mecânicas para a sociedade moderna. A emergência da fotografia e do cinema são, para Benjamin, sintomas do declínio da tradição cultural de uma sociedade que passava a ser dominada pela "estetização da política" (BENJAMIN, 2012, p. 212) e pelo culto à guerra, cujas consequências levaram ao fascismo. Nesse sentido, Benjamin foi categórico ao explicitar as implicações históricas provocadas pela introdução da fotografia. Flusser, por sua vez, teria sido "o primeiro a perceber a profundidade das ideias de Benjamin sobre a fotografia e a reprodução técnica" (SELIGMANN-SILVA, 2009, p. 7), expandindo esse debate. Segundo Meulen (2010, p. 185), Flusser compreendeu as limitações históricas de Benjamin e problematizou as imagens técnicas no contexto das "novas mídias" (principalmente na televisão e nos dispositivos digitais), indo além do cinema e da fotografia.

Se Benjamin foi um dos grandes críticos do historicismo e percebeu que a era da reprodução técnica é uma era da pós-tradição (para ele na era da fotografia não caberia mais se fazer uma diferença entre cópia e original nem se falar de autenticidade), Flusser vai notar, por sua vez, que o historicismo era o resultado de uma luta milenar entre a escrita e as imagens e que o homem pós-histórico é fruto do novo 
triunfo das imagens sobre a escritura (SELIGMANN-SILVA, 2009, p. 8).

Em resumo, podemos dizer que o caminho aberto por Benjamin para se compreender o papel das imagens técnicas foi posteriormente explorado pelo próprio Flusser: um pensador que percebeu a relevância dessa questão e reforçou a necessidade de uma reflexão crítica sobre essas imagens. Seu alerta "(...) coincide com uma crítica do funcionalismo - que permanece urgente e na ordem do dia" (SELIGMANN-SILVA, 2014, p. 227). Portanto, a cultura imagética proporcionada pelas mídias eletrônicas e digitais é, para Flusser, um sério desafio para a consciência histórica e para o pensamento crítico (MEULEN, 2010, p. 186).

\section{Flusser e Peirce: máquinas semióticas e os diagramas}

Como vimos anteriormente, Arlindo Machado $(1999,2005)$ entende que os aparelhos de criação e reprodução de imagens técnicas, são, na verdade, máquinas semióticas, cujo exemplo mais notório é a câmera fotográfica: "é com base na sua definição semiótica e tecnológica que se constroem hoje as máquinas contemporâneas de produção simbólica audiovisual" (MACHADO, 2005, p. 74). Embora Flusser tenha dedicado um livro especial a essa máquina em A Filosofia da Caixa Preta (2011b), a fotografia, na verdade, foi um pretexto para que Flusser pudesse apontar o que se encontra por trás da sociedade "pós-histórica" (MACHADO, 2005). Por sua vez, o fato de Machado caracterizar a câmera fotográfica como uma máquina semiótica² convoca uma inevitável aproximação com o pensamento de um dos fundadores da teoria semiótica moderna, o filósofo e lógico Charles Peirce (NÖTH; 2001, 2009).

A semiótica de Peirce contempla um sofisticado aparato metodológico para compreender como operam as relações sígnicas no universo. Seu interesse principal era desvendar como o pensamento deliberado poderia ser capaz de produzir conhecimento no longo curso do tempo, tendo os signos como elementos mediadores entre a realidade e uma determinada mente (não necessariamente humana) (SANTAELLA, 2004). Nesse sentido,

2 Nöth (2009, p. 27) reconhece a relevância de Flusser na análise dos aparelhos produtores de signos para a história da mídia. Contudo, Nöth propõe uma distinção entre o conceito de aparelho produtor de signos e aparelho processador de signos, a fim de esclarecer, de maneira mais precisa, o conceito de máquinas semióticas. 
a semiótica de Peirce propõe que o signo, elemento central nessa mediação, está em uma relação triádica entre duas outras entidades: o objeto (ou realidade, num sentido mais amplo) e o interpretante (o efeito interpretativo em uma mente). $\mathrm{O}$ interesse pelas diferentes maneiras como os signos operam nessa relação levou Peirce a propor um sistema classificatório para mapear e caracterizar as múltiplas manifestações sígnicas (SANTAELLA, 1995).

Um dos tipos de signo trabalhados por Peirce é justamente a imagem. De acordo com a semiótica de Peirce, a ação da imagem como um signo pode ser compreendida sob diversas perspectivas. Uma delas diz respeito à forma como a imagem se relaciona com o objeto representado. De maneira bastante resumida, essa relação pode se estabelecer através de um compartilhamento de qualidades e semelhanças formais; através de uma conexão existencial e afirmativa; ou através de um hábito ou convenção.

Peirce identificou um tipo particular de imagem, cujos efeitos interpretativos estariam diretamente relacionados ao raciocínio lógico: os diagramas. Por apresentar semelhanças estruturais com o objeto representado, os diagramas seriam signos estimulantes de descobertas heurísticas. O exercício de manipulação de diagramas percorre todos os tipos de raciocínio, o que os habilita a agir como poderosas ferramentas em métodos de investigação científica (STJERNFELT, 2013). Nesse sentido, os diagramas ocupam um lugar relevante na semiótica de Peirce, uma vez que suas características estimulam o pensamento sobre o próprio pensamento, atuando como uma espécie de "máquina formal para o raciocínio" (FRANCO; BORGES, 2015). Como o próprio Arlindo Machado indica, o diagrama é um tipo de signo que organiza e esclarece o pensamento, "uma construção do pensamento tão sofisticada que, sem ela, provavelmente não teria sido possível o desenvolvimento de ciências como a biologia, a geografia, a geometria, a astronomia e a medicina" (MACHADO, 2001, p. 25).

Há, portanto, uma possível articulação entre a tecnoimaginação de Flusser e o pensamento diagramático de Peirce. Ambos os autores não estão aparentemente tão distantes ${ }^{3}$. Segundo Hanke (2004, p. 67), Flusser se insere na tradição da semiótica ocidental, cujos conceitos se manifestam, por exemplo, por meio da centralidade ocupada pela noção de código.

3 Michael Hanke (2004, p. 60) aponta que Flusser frequentou cursos de lógica simbólica ministrados pelo prof. Leônidas Hegenberg, um dos tradutores de Peirce no Brasil. 
Em convergência com outros autores que compõem a assim chamada teoria da mídia alemã, Flusser afirma que as características do código estruturam o pensar, o querer e o sentir. Com a emergência dos novos códigos não lineares, deparamo-nos, verdadeiramente, com outros sentidos para o mundo e a vida diferentes daqueles que vigoravam anteriormente (FELINTO; SANTAELLA, 2012, p. 173).

A aproximação entre o pensamento diagramático e as imagens técnicas foi, de maneira mais específica, trabalhada por Hadler e Irrgang (2014, p. 72). Esses autores destacam as implicações epistemológicas das imagens técnicas. Por serem construídas por um processo de codificação, as imagens técnicas poderiam facilmente projetar conceitos. Ou seja, as imagens técnicas concretizam modelos abstratos e, assim, criam algo novo, ao invés de simplesmente representar coisas. De maneira análoga, essa propriedade também está presente nos diagramas. "Quando se trata de objetos inteligíveis (modelos, teorias etc.), um diagrama é mais que uma representação; ele constitui seu objeto tornando-o visível - uma operação hermenêutica recursiva" (HADLER; IRRGANG, 2014, p. 74).

Em resumo, tanto Flusser quanto Peirce propõem que a imagem é, potencialmente, capaz de articular conceitos e promover a reflexão sobre a própria maneira de se raciocinar. Assim, a congruência dos estudos da imagem nos campos da semiótica e das ciências cognitivas abriria portas para a investigação sobre os modelos de processamento mental do conhecimento (NÖTH, 2009; SANTAELLA; NÖTH, 1997), um tema que certamente seria do interesse de Flusser.

\section{Considerações finais}

Nosso objetivo central foi promover uma revisão sobre a imagem técnica, tendo a obra de Flusser como principal alicerce. Para isso, fizemos uma recapitulação de sua escalada da abstração, a fim de identificar como a imagem está situada no edifício argumentativo do autor. Em seguida, explicitamos o problema colocado pela emergência da imagem técnica, cujo processamento ocorre no interior de uma caixa preta: um aparelho opaco, limitado por funções de input e output, operado por um funcionário que, via de regra, desconhece seu algoritmo interno. Flusser nos alerta que, dada a relevância das imagens técnicas em nossa atual sociedade, faz- 
se necessário adquirir uma habilidade crítica de leitura sobre esse tipo de signo, caso contrário, continuaremos a ser meros funcionários alienados ao funcionamento desses aparelhos. Uma das alternativas levantadas para estimular o exercício crítico sobre o problema das imagens encontra-se na arte contemporânea. Outra alternativa, sugerida neste artigo, consiste em desenvolvermos o queFlusser denominou detecnoimaginação. Defendemos que essa modalidade de pensamento visual encontra ressonância com outros pensadores que também se interessaram pelo tema das imagens, tais como Walter Benjamin e Charles Peirce.

Certamente, as aproximações aqui sugeridas entre o pensamento de Vilém Flusser com esses autores merecem um desdobramento futuro mais aprofundado. Ao apontar essas semelhanças, propusemos um convite para o confronto intelectual entre pensadores que, embora pertençam a tradições distintas, compartilham afinidades temáticas. Como indica o título deste artigo, trata-se de apontamentos e diálogos que a tecnoimaginação de Flusser pode estabelecer com a epistemologia da imagem.

Tal como Flusser, acreditamos que uma reflexão crítica sobre as imagens encontra-se na base de qualquer análise sobre fenômenos comunicacionais contemporâneos. Desde o marketing político, passando pelas fotografias selfies ou mesmo a cobertura jornalística factual, a imagem técnica inevitavelmente será colocada sob julgamento e apreciação pública. Devemos, portanto, ter a consciência de que essas imagens são produtos de um aparelho (ou máquina semiótica) bastante sagaz, habilmente construída para gerar certos tipos de representação. Nem por isso devemos esquecer que as imagens técnicas também são portadoras da própria história do pensamento humano, ao carregarem os rastros de uma trajetória de abstração que começou com um simples gesto de estranhamento do mundo dos objetos tridimensionais e alcançou uma dimensão fluida e etérea dos pixels e bits.

\section{REFERÊNCIAS}

BAITELLO JR., Norval. Prefácio: a escalada da abstração. In: FLUSSER, Vilém. O universo das imagens técnicas: elogio da superficialidade. São Paulo: Annablume, 2008.

BENJAMIN, Walter. Magia e técnica, arte e política: ensaios sobre literatura e história da cultura. 8. ed. São Paulo: Brasiliense, 2012. 
BENJAMIN, Walter. Escritos sobre mito e linguagem. São Paulo: Duas Cidades, Ed. 34, 2013.

BENJAMIN, Walter. Baudelaire e a modernidade. Trad. João Barrento. Belo Horizonte: Autêntica editora, 2015.

CAMPOS, Haroldo de. A língua Pura na teoria da tradução de Walter Benjamin. Revista USP. São Paulo, n. 33, p. 160-171, 1997. Disponível em: <http://www.revistas.usp.br/revusp/article/ view/35052/37791>. Acesso em: 30 mai. 2017.

CARDOSO, Rafael. Introdução. In: FLUSSER, Vilém. 0 mundo codificado: por uma filosofia do design e da comunicação. São Paulo: Cosac Naify, 2007.

FELINTO, Erick; SANTAELLA, Lucia. O explorador de abismos: Vilém Flusser e o pós-humanismo. São Paulo: Paulus, 2012.

FLUSSER, Vilém. O mundo codificado: por uma filosofia do design e da comunicação. São Paulo: Cosac Naify, 2007.

FLUSSER, Vilém. O universo das imagens técnicas: elogio da superficialidade. São Paulo: Annablume, 2008.

FLUSSER, Vilém. Nossas imagens. In: FLUSSER, Vilém. Pós-história: vinte instantâneos e um modo de usar. São Paulo: Annablume, 2011a.

FLUSSER, Vilém. Filosofia da caixa preta: ensaios para uma futura filosofia da fotografia. São Paulo: Annablume, 2011b.

FLUSSER, Vilém. Comunicologia: reflexões sobre o futuro. São Paulo: Martins Fontes - selo Martins, 2014.

FRANCO, Juliana Rocha; BORGES, Priscila. O conceito de diagrama em Peirce: uma leitura semiótica para além da Gramática Especulativa. In: 16o Encontro internacional sobre Pragmatismo, São Paulo, v. 1. p. 74-76, 2015

HADLER, Florian; IRRGANG, Daniel. Nonlinearity, Multilinearity, Simultaneity: Notes on Epistemological Structures. In: MOURA, H. et al. (orgs.). Proceedings of the Interactive Narratives, 2014. ISBN: 978-0-9939520-0-5. Disponível em: < https://is.gd/ouk4Da>. Acesso em 09 mai. 2019.

HANKE, Michael. A comunicologia segundo Vilém Flusser. Galáxia: Revista do Programa de PósGraduação em Comunicação e Semiótica. n. 7, abril de 2004. Disponível em: <https://revistas.pucsp. br/galaxia/article/download/1371/854>. Acesso em: 09 mai. 2019.

MACHADO, Arlindo. Repensando Flusser e as imagens técnicas. Revista de Comunicação e Linguagens: Real vs. Virtual, n. 25/26, p. 31-45, 1999.

MACHADO, Arlindo. $O$ quarto iconoclasmo e outros ensaios hereges. Rio de Janeiro: Rios Ambiciosos, 2001

MACHADO, Arlindo. Tecnologia e arte contemporânea: como politizar o debate. Revista de Estudios Sociales, no. 22, dezembro de 2005, p. 71-79. Disponível em: <https://doi.org/10.7440/ res22.2005.05>. Acesso em: 05 ago. 2018.

MEULEN, Sjoukje van der. Between Benjamin and McLuhan:Vilém Flusser's MediaTheory. New German Critique, no. 2, v. 37, agosto de 2010. p. 180-207. doi: https://doi.org/10.1215/0094033X-2010-010. Acesso em: 09 mai. 2019. 
NÖTH, Winfried. Máquinas semióticas. Galáxia: Revista do Programa de Pós-Graduação em Comunicação e Semiótica. n. 1, 2001. Disponível em: <https://revistas.pucsp.br/index.php/galaxia/ article/view/1057>. Acesso em: 11 ago. 2018.

NÖTH, Winfried. On the Instrumentality and Semiotic Agency of Signs, Tools, and Intelligent Machines. Cybernetics \& Human Knowing, Volume 16, N. 3-4, p. 11-36. 2009.

PLAZA, Julio. Tradução Intersemiótica. São Paulo: Perspectiva, 2013.

SANTAELLA, Lucia. Teoria geral dos signos: semiose e autogeração. São Paulo: Pioneira, 1995.

SANTAELLA, Lucia. O método anticartesiano de C. S. Peirce. São Paulo: Editora UNESP, 2004.

SANTAELLA, Lucia. Linguagens líquidas na era da mobilidade. São Paulo: Paulus, 2007.

SANTAELLA, Lucia. NÖTH, Winfried. Imagem: cognição, semiótica, mídia. São Paulo: lluminuras, 1997.

SELIGMANN-SILVA, M. De Flusser a Benjamin - do pós-aurático às imagens técnicas. Flusser Studies, 8:1-17. Disponível em: <https://philpapers.org/rec/SELDFA>. Acesso em: 05 ago. 18.

SELIGMANN-SILVA, M. Vilém Flusser: entre a tradução como criação de si e a pós-tradução. Cadernos de Tradução, Florianópolis, p. 223-234, out. 2014. ISSN 2175-7968. Disponível em: $<$ https://periodicos.ufsc.br/index.php/traducao/article/view/2175-7968.2014v3nespp223>. Acesso em: 09 maio 2019.

STJERNFELT, Frederik. Diagramas: foco para uma epistemologia peirceana. In: QUEIROZ, J.; MORAES, L. (Org.). A lógica de diagramas de Charles Sanders Peirce: implicações em ciência cognitiva, lógica e semiótica. Juiz de Fora : Editora UFJF, 2013.

Data do recebimento: 07 fevereiro 2019

Data da aprovação: 25 junho 2019 


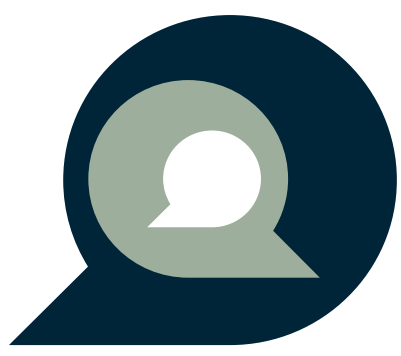

